\title{
SEASONAL AND INTERANNUAL VARIABILITY IN ATMOSPHERIC TURBIDITY OVER SOUTH AFRICA
}

\author{
HELEN C. POWER ${ }^{\mathrm{a}, *}$ and CORT J. WILLMOTT ${ }^{\mathrm{b}}$ \\ a Department of Geography, University of South Carolina, Columbia, SC 29208, USA \\ ${ }^{\mathrm{b}}$ Department of Geography, University of Delaware, Newark, DE 19716, USA
}

Received 23 February 2000

Revised 22 October 2000

Accepted 26 October 2000

\begin{abstract}
Aerosols affect climate by attenuating solar radiation and acting as cloud condensation nuclei. Despite their importance in the climate system, our understanding of the time-space variability of aerosols is fragmentary. Measurements and reliable estimates of atmospheric turbidity - the total column amount of aerosol-are scarce in most countries and this is especially true in the Southern Hemisphere. Very little is known about the seasonal, interannual and spatial variability of aerosols over the southern half of the globe.

In this paper, we estimate monthly averaged atmospheric turbidity from surface climate data at eight locations in South Africa, regardless of cloud cover. Findings include new estimates of turbidity trends and variability over South Africa. Seasonal trends are evident at many stations, although there is no consistent trend. Over recent decades, turbidity has generally been stable at six of the eight stations. Our methodology can be applied at any location where the requisite climate data are available and, therefore, holds promise for a more complete, and possibly global, climatology of aerosols. Copyright (C) 2001 Royal Meteorological Society.
\end{abstract}

KEY WORDS: aerosols; turbidity; climate; radiation; modelling; South Africa

\section{INTRODUCTION}

Quantifying the processes by which aerosols affect climate is crucial to understanding how humans influence climate and how we may alter climate in the future; this is especially important as anthropogenic emissions of aerosols continue to increase (Penner et al., 1994; Wolf and Hidy, 1997; Kiehl, 1999). Aerosols are known to affect climate in two ways. They influence the planetary albedo by scattering and absorbing radiation (direct effect) and they modify the physical and radiative properties of clouds by acting as cloud condensation nuclei (indirect effect). Although the exact magnitude of aerosol-induced radiative forcing is uncertain, aerosols are thought to have a net cooling effect. Thus, they may mask the warming effects of anthropogenic increases in greenhouse gases (Wigley, 1989; Kaufman et al., 1991; Charlson et al., 1992; Penner et al., 1992; Christopher et al., 1996; Kiehl, 1999). Indeed, aerosols may have delayed the detection of global warming due to greenhouse gases (Wigley and Raper, 1992).

A key reason for the uncertainty about aerosol-climate interactions is that aerosols demonstrate high variability, both spatially and temporally, and the extent of their variability has not been fully investigated. There is a paucity of reliable data on the amount of aerosol in the atmosphere. Conventional techniques for quantifying atmospheric turbidity - the amount of aerosol integrated vertically through the atmosphere - typically require costly and sophisticated instrumentation and clear-sky conditions (e.g. Dutton et al., 1994; Holben et al., 1998). Recent satellite estimates of turbidity are also restricted to clear-sky conditions and non-terrestrial regions (Tanré et al., 1996; Husar et al., 1997). The clear-sky restriction produces gaps in the turbidity record, as well as a possible bias because cloudless skies are associated with a limited set of synoptic situations.

\footnotetext{
* Correspondence to: Department of Geography, University of South Carolina, Columbia, SC 29208, USA; e-mail: power@sc.edu
}

Copyright (C) 2001 Royal Meteorological Society 
In addition to these potential biases, atmospheric turbidity measurements and estimates are not optimally distributed in space. In other words, turbidity studies are geographically biased. With only a few, mostly recent, exceptions (Shaw, 1982; Herber et al., 1991; Villevalde et al., 1994; Herber et al., 1996; Yatko and Garrison, 1996; Holben et al., 1998; Veefkind and de Leeuw, 1998), most studies have focused on Northern Hemisphere turbidities (e.g. Sadler, 1978; Cerf, 1980; Freund, 1983; Prodi et al., 1984; Al-Jamal et al., 1987; Gueymard, 1994; Holben et al., 1996; Jacovides et al., 1996a,b; Adeyefa et al., 1997; Blumthaler et al., 1997; Maduekwe and Chendo, 1997; Pinker et al., 1997; Gueymard and Garrison, 1998; Kambezidis et al., 1998; Chiapello et al., 1999; Russell et al., 1999; Veefkind et al., 1999; von Hoyningen-Huene et al., 1999). Given that there are distinct differences in aerosol sources, emission rates and sampling between the Southern and Northern Hemispheres - the majority of anthropogenic aerosols are emitted in the Northern Hemisphere (Penner et al., 1994; Trenberth, 1996; Wolf and Hidy, 1997) - there has been a Northern Hemisphere sampling bias which has led to questionable inferences about atmospheric turbidity over large parts of the Southern Hemisphere.

Owing to such temporal and spatial constraints, the turbidity record contains data for too few locations, for mostly short time periods and primarily for the Northern Hemisphere. There appears to be no reliable, long-term record of atmospheric turbidity for determining trends in aerosol variability, especially in the Southern Hemisphere.

The present investigation employed a recently developed model to estimate monthly averaged turbidity from surface climate data at eight locations in South Africa, regardless of cloud cover. The temporal extent of the South African historical climate record provided the opportunity to examine both seasonal and long-term variability in turbidity in the Southern Hemisphere. This methodology makes use of available climate data - and is not restricted to clear-sky conditions-which allows the estimation and presentation of a previously unavailable climatology of turbidity.

\section{ATMOSPHERIC TURBIDITY MODEL}

In addition to aerosol attenuation, solar radiation passing through the atmosphere is attenuated by molecular scattering and absorption by ozone, nitrogen dioxide, water vapour, carbon dioxide and oxygen. In the absence of clouds, surface irradiance can be modelled as a function of these attenuation processes. Many existing models then can be inverted to obtain the aerosol contribution wherever radiation is measured and the other components are measured or adequately estimated. Most of these models, however, can only estimate instantaneous turbidity since they are dependent on optical air mass (a function of the position of the sun) and cannot be analytically integrated over time.

Power (1999, 2001a) significantly reduced this limitation by using a physically based, high-resolution spectral radiation model (Gueymard, 1995) to parameterize clear-sky beam irradiance with polynomial expansions of the sine of the solar-elevation angle. This structure permits analytic integration and inversion and, in turn, provides an expression for estimating daily averages of Angström's turbidity coefficient $^{1}(\beta)$. The model is

$$
\hat{\bar{\beta}}=c_{1}^{-1} \ln \left(\frac{H_{b c}}{k E_{0 n} c_{0} \exp \left(c_{2} \bar{w}\right) \bar{u}_{o}^{c_{3}}\left(\frac{\bar{p}}{p_{0}}\right)^{c_{4}} \bar{u}_{n}^{c_{5}} \sum_{i=0}^{7} \varphi_{i} J_{i+1}}\right),
$$

where $c_{i}$ and $\varphi_{i}$ are coefficients obtained from a linear least-squares fit to the reference data (Appendix A), $H_{b c}$ is the 'potential' daily clear-sky beam irradiation on a horizontal surface ( $\mathrm{J} \mathrm{m}^{-2}$; see below), $k=24 / \pi(\mathrm{h}), E_{0 n}$ is the broadband extraterrestrial irradiance at normal incidence and actual earth-sun distance $\left(\mathrm{W} \mathrm{m}{ }^{-2}\right), w$ is precipitable water $(\mathrm{cm}), u_{o}$ is total column ozone (atm-cm), $p$ is atmospheric pressure $(\mathrm{mb}), p_{0}$ is the sea-level standard pressure $(\mathrm{mb}), u_{n}$ is total column nitrogen dioxide (atm-cm) and the overbars denote the daily averages of each of the respective quantities. The term $J_{i}$ represents 


$$
J_{i}=\int_{0}^{\omega_{0}} \sin ^{i} h \mathrm{~d} \omega
$$

where $h$ is the solar-elevation angle, $\omega$ is the hour angle and $\omega_{0}$ is the hour angle at sunrise. In Equation (1), a solar-angle correction factor $(\sin h)$ is incorporated in $J_{i+1}$. Analytic solutions to Equation (2) were initially proposed by Gueymard (1993) and appear in Appendix B.

Potential daily clear-sky beam irradiation on a horizontal surface $\left(H_{b c}\right)$ is the beam radiation that would have been incident if the sky had been clear all day. Thus, it is a theoretical, 'potential' quantity that is only ever observed on days that are cloud free. Following Louche et al. (1991), Gueymard (1993) and Power $(2001 \mathrm{~b})$, monthly averages of the potential daily clear-sky beam irradiation $\left(\bar{H}_{b c}\right)$ can be estimated from

$$
\bar{H}_{b c}=\bar{H}_{b} \bar{S}(\bar{s})^{-1} \quad\left(\mathrm{~J} \mathrm{~m}^{-2}\right),
$$

where $H_{b}$ is the observed daily beam irradiation $\left(\mathrm{J} \mathrm{m}^{-2}\right), S$ is the astronomical day duration (daylength) and $s$ is the duration of bright sunshine. ${ }^{2}$ In Equation (3), the overbars denote the monthly average values of each of the respective quantities. Because Equation (3) provides monthly estimates of potential irradiation, forcing Equation (1) with monthly averaged climate data permits monthly averaged turbidity estimates. In this way, turbidity can be estimated regardless of cloud cover.

Power $(1999,2001 \mathrm{a})$ evaluated Equation (1) (using Equation (3) to estimate $\bar{H}_{b c}$ ) with monthly turbidity and climate data from five stations in Europe and North America. Willmott's absolute-difference-based index of agreement $(d)$ (Willmott et al., 1985) ${ }^{3}$ was 0.70 , while the mean-absolute error was 0.02 for a mean monthly averaged $\beta$ of 0.09 .

\section{ESTIMATES OF SOUTH AFRICAN TURBIDITY}

Estimating monthly averages of Ångström's turbidity coefficient $\left(\bar{\beta}_{m}\right)$ from Equations (1) and (3) requires monthly averages of $H_{b}, s, w, u_{o}, p$ and $u_{n}$. Values of $E_{0 n}, \omega_{0}$ and $S$ can be easily calculated, for any location, from established astronomical relationships.

\subsection{Climate forcing}

In the Southern Hemisphere, there are few locations where the requisite climate data are available. The main constraint is the availability of accurate solar radiation observations. South Africa, however, offers a well-maintained network of first-order weather stations. The South African Weather Bureau (SAWB) provided requisite data for eight stations in South Africa. Four of the stations (Alexander Bay, Cape Town, Durban and Port Elizabeth) are coastal, while Bloemfontein, Grootfontein, Pretoria and Upington are located inland at elevations above $800 \mathrm{~m}$ (Table I, Figure 1). A temporal 'window' common to the

Table I. Latitude, longitude, elevation, period and length of record, and population for each of the eight climate stations for which monthly estimates of Angstrom's turbidity coefficient $(\beta)$ were made

\begin{tabular}{lllcccr}
\hline & $\begin{array}{l}\text { Latitude } \\
(\mathrm{S})\end{array}$ & $\begin{array}{l}\text { Longitude } \\
(\mathrm{E})\end{array}$ & $\begin{array}{l}\text { Elevation } \\
(\mathrm{m})\end{array}$ & Period & $\begin{array}{l}\text { Length } \\
\text { (years) }\end{array}$ & Population \\
\hline Alexander Bay & 28.57 & 16.53 & 21 & $1959-1984$ & 26 & $<100000$ \\
Bloemfontein & 29.10 & 26.30 & 1351 & $1959-1993$ & 35 & 300000 \\
Cape Town & 33.97 & 18.60 & 44 & $1966-1995$ & 30 & 2350000 \\
Durban & 29.96 & 30.95 & 8 & $1978-1991$ & 14 & 1130000 \\
Grootfontein & 31.48 & 25.03 & 1270 & $1969-1990$ & 22 & $<100000$ \\
Port Elizabeth & 33.98 & 25.60 & 60 & $1959-1991$ & 33 & 853000 \\
Pretoria & 25.73 & 28.18 & 1330 & $1965-1997$ & 33 & 1080000 \\
Upington & 28.40 & 21.27 & 836 & $1969-1992$ & 24 & $<100000$ \\
\hline
\end{tabular}

Population figures are 1991 estimates (United Nations, 1999) for the greater metropolitan area of each location. 


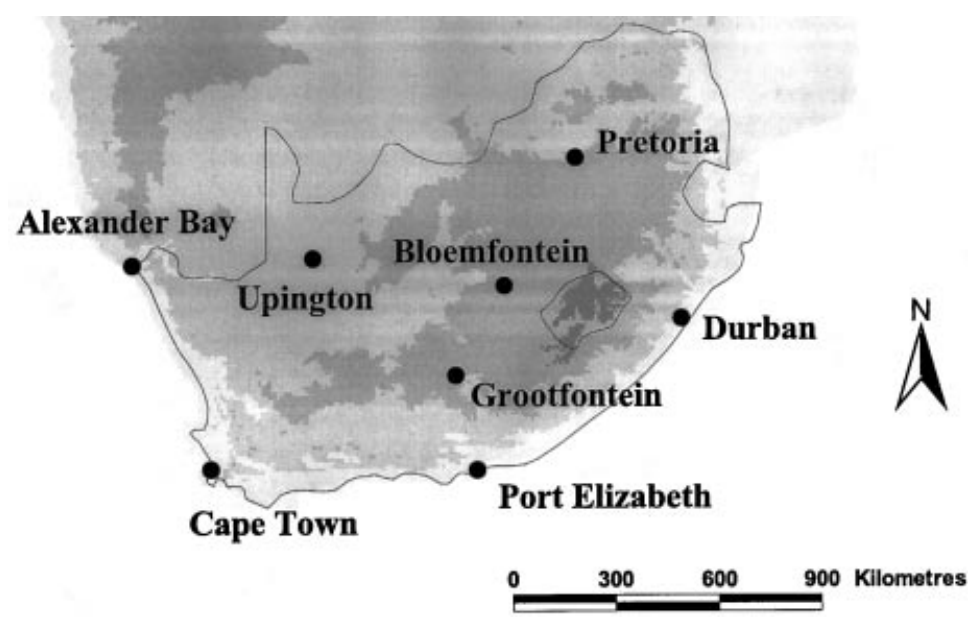

Figure 1. Relative elevation in Southern Africa (grey-scale shading), with the locations of the SAWB climate stations for which the requisite data for making turbidity estimates were available

station data prescribed the time period over which monthly estimates of turbidity could be made for each station. Overall record lengths average 27 years and range between 14 and 35 years (Table I).

As input to Equation (3), $\bar{H}_{b}$ was computed as the difference between the monthly averaged global and diffuse components. Both the global and the diffuse irradiances were measured with Kipp and Zonen CM5 pyranometers, and the SAWB applied shadowband correction factors to the diffuse data. The uncertainty associated with the monthly averaged global and diffuse irradiation is estimated at less than $2 \%$ (D. Esterhuyse, personal communication, 2000). Bright sunshine duration $(s)$ was measured with Campbell-Stokes sunshine recorders. These instruments have an expected root-mean-square error of approximately $4.1 \%$ of the monthly percentage of possible sunshine (Benson et al., 1984).

As input to Equation (1), mean monthly estimates of $w$ were computed using Gueymard's (1994) algorithm as a function of monthly averaged air temperature and monthly averaged relative humidity. Monthly averaged $u_{o}$ was estimated, using Van Heuklon's (1979) algorithm, from latitude, longitude and the climatologically average day of the month. ${ }^{4}$ Monthly averaged $u_{n}$ was estimated according to the size (population) of each location. ${ }^{5}$ A value of 2.0 matm-cm was assigned to those cities with a population over 1 million, 1.0 matm-cm was used for cities with populations between 100000 and 1 million, and a value of 0.15 matm-cm was assigned for the remaining locations.

\subsection{Seasonal variability}

The most striking result is the relatively low levels of turbidity in South Africa (Table II); long-term averages of $\hat{\bar{\beta}}_{m}$ range between 0.013 and 0.047 . Highest turbidity occurs in the main centres (Pretoria, Durban and Cape Town), while the lowest turbidity occurs in the small township of Alexander Bay located on the Atlantic coast near the Namibian border. In the larger cities, anthropogenic aerosols may be augmenting the turbidity signal.

Many stations exhibit marked seasonal trends in turbidity. Bloemfontein, Grootfontein and Pretoria (Figure 2), for example, exhibit typical summer highs and winter lows in turbidity that have been observed elsewhere (e.g. Peterson and Flowers, 1977; Uboegbulam and Davies, 1983; Louche et al., 1987; Garrison and Sahami, 1995). These three stations are located in the mountains at elevations of 1351, 1270 and 1330 $\mathrm{m}$, respectively (Table I, Figure 1). In the summer, they are probably affected by low-pressure systems that draw in moist air from the Indian Ocean. Higher precipitable water in the summer (Figure 3) can enhance hygroscopic aerosol growth and may contribute to the summer highs in turbidity at these three locations. 
Table II. Long-term monthly and annual averages and standard deviations (in parentheses) of Ångström's turbidity coefficients estimated at each of the eight climate stations in South Africa

\begin{tabular}{|c|c|c|c|c|c|c|c|c|}
\hline & $\mathrm{AB}$ & BL & CT & $\mathrm{DN}$ & GR & $\mathrm{PE}$ & PR & UP \\
\hline January & $\begin{array}{c}0.007 \\
(0.003)\end{array}$ & $\begin{array}{r}0.026 \\
(0.014)\end{array}$ & $\begin{array}{c}0.021 \\
(0.010)\end{array}$ & $\begin{array}{c}0.021 \\
(0.014)\end{array}$ & $\begin{array}{c}0.022 \\
(0.013)\end{array}$ & $\begin{array}{c}0.021 \\
(0.018)\end{array}$ & $\begin{array}{r}0.059 \\
(0.021)\end{array}$ & $\begin{array}{c}0.02 \\
(0.011)\end{array}$ \\
\hline February & $\begin{array}{r}0.007 \\
(0.004)\end{array}$ & $\begin{array}{c}0.025 \\
(0.013)\end{array}$ & $\begin{array}{c}0.021 \\
(0.011)\end{array}$ & $\begin{array}{c}0.017 \\
(0.009)\end{array}$ & $\begin{array}{c}0.027 \\
(0.014)\end{array}$ & $\begin{array}{c}0.021 \\
(0.012)\end{array}$ & $\begin{array}{c}0.071 \\
(0.023)\end{array}$ & $\begin{array}{r}0.028 \\
(0.013)\end{array}$ \\
\hline March & $\begin{array}{r}0.004 \\
(0.003)\end{array}$ & $\begin{array}{c}0.018 \\
(0.011)\end{array}$ & $\begin{array}{r}0.016 \\
(0.011)\end{array}$ & $\begin{array}{c}0.025 \\
(0.019)\end{array}$ & $\begin{array}{c}0.013 \\
(0.008)\end{array}$ & $\begin{array}{c}0.021 \\
(0.017)\end{array}$ & $\begin{array}{c}0.058 \\
(0.020)\end{array}$ & $\begin{array}{r}0.015 \\
(0.009)\end{array}$ \\
\hline April & $\begin{array}{r}0.006 \\
(0.006)\end{array}$ & $\begin{array}{r}0.015 \\
(0.009)\end{array}$ & $\begin{array}{c}0.020 \\
(0.018)\end{array}$ & $\begin{array}{r}0.019 \\
(0.007)\end{array}$ & $\begin{array}{c}0.011 \\
(0.007)\end{array}$ & $\begin{array}{r}0.019 \\
(0.015)\end{array}$ & $\begin{array}{r}0.044 \\
(0.020)\end{array}$ & $\begin{array}{r}0.018 \\
(0.011)\end{array}$ \\
\hline May & $\begin{array}{c}0.010 \\
(0.009)\end{array}$ & $\begin{array}{c}0.010 \\
(0.005)\end{array}$ & $\begin{array}{c}0.032 \\
(0.024)\end{array}$ & $\begin{array}{c}0.030 \\
(0.011)\end{array}$ & $\begin{array}{c}0.019 \\
(0.017)\end{array}$ & $\begin{array}{c}0.019 \\
(0.014)\end{array}$ & $\begin{array}{c}0.031 \\
(0.013)\end{array}$ & $\begin{array}{r}0.015 \\
(0.015)\end{array}$ \\
\hline June & $\begin{array}{c}0.017 \\
(0.019)\end{array}$ & $\begin{array}{c}0.013 \\
(0.014)\end{array}$ & $\begin{array}{r}0.030 \\
(0.023)\end{array}$ & $\begin{array}{c}0.038 \\
(0.027)\end{array}$ & - & $\begin{array}{c}0.018 \\
(0.020)\end{array}$ & $\begin{array}{r}0.027 \\
(0.013)\end{array}$ & $\begin{array}{r}0.016 \\
(0.012)\end{array}$ \\
\hline July & $\begin{array}{c}0.013 \\
(0.011)\end{array}$ & $\begin{array}{c}0.008 \\
(0.006)\end{array}$ & $\begin{array}{c}0.030 \\
(0.021)\end{array}$ & $\begin{array}{c}0.036 \\
(0.012)\end{array}$ & $\begin{array}{c}0.005 \\
(0.004)\end{array}$ & $\begin{array}{c}0.020 \\
(0.020)\end{array}$ & $\begin{array}{c}0.031 \\
(0.012)\end{array}$ & $\begin{array}{r}0.013 \\
(0.009)\end{array}$ \\
\hline August & $\begin{array}{c}0.017 \\
(0.013)\end{array}$ & $\begin{array}{c}0.016 \\
(0.013)\end{array}$ & $\begin{array}{c}0.039 \\
(0.019)\end{array}$ & $\begin{array}{r}0.043 \\
(0.013)\end{array}$ & $\begin{array}{c}0.013 \\
(0.008)\end{array}$ & $\begin{array}{r}0.030 \\
(0.022)\end{array}$ & $\begin{array}{r}0.039 \\
(0.012)\end{array}$ & $\begin{array}{r}0.025 \\
(0.010)\end{array}$ \\
\hline September & $\begin{array}{c}0.018 \\
(0.013)\end{array}$ & $\begin{array}{c}0.028 \\
(0.017)\end{array}$ & $\begin{array}{c}0.038 \\
(0.020)\end{array}$ & $\begin{array}{c}0.033 \\
(0.011)\end{array}$ & $\begin{array}{r}0.023 \\
(0.016)\end{array}$ & $\begin{array}{r}0.036 \\
(0.025)\end{array}$ & $\begin{array}{r}0.047 \\
(0.015)\end{array}$ & $\begin{array}{r}0.027 \\
(0.013)\end{array}$ \\
\hline October & $\begin{array}{c}0.014 \\
(0.010)\end{array}$ & $\begin{array}{c}0.031 \\
(0.016)\end{array}$ & $\begin{array}{r}0.034 \\
(0.013)\end{array}$ & $\begin{array}{c}0.028 \\
(0.012)\end{array}$ & $\begin{array}{r}0.026 \\
(0.014)\end{array}$ & $\begin{array}{c}0.033 \\
(0.018)\end{array}$ & $\begin{array}{c}0.053 \\
(0.016)\end{array}$ & $\begin{array}{r}0.032 \\
(0.008)\end{array}$ \\
\hline November & $\begin{array}{r}0.010 \\
(0.006)\end{array}$ & $\begin{array}{r}0.028 \\
(0.013)\end{array}$ & $\begin{array}{c}0.032 \\
(0.015)\end{array}$ & $\begin{array}{r}0.026 \\
(0.014)\end{array}$ & $\begin{array}{r}0.023 \\
(0.013)\end{array}$ & $\begin{array}{r}0.035 \\
(0.015)\end{array}$ & $\begin{array}{r}0.055 \\
(0.016)\end{array}$ & $\begin{array}{r}0.027 \\
(0.012)\end{array}$ \\
\hline December & $\begin{array}{c}0.008 \\
(0.006)\end{array}$ & $\begin{array}{r}0.022 \\
(0.020)\end{array}$ & $\begin{array}{c}0.024 \\
(0.012)\end{array}$ & $\begin{array}{c}0.025 \\
(0.025)\end{array}$ & $\begin{array}{c}0.021 \\
(0.012)\end{array}$ & $\begin{array}{c}0.023 \\
(0.014)\end{array}$ & $\begin{array}{c}0.052 \\
(0.017)\end{array}$ & $\begin{array}{r}0.021 \\
(0.015)\end{array}$ \\
\hline Annual & $\begin{array}{c}0.013 \\
(0.011)\end{array}$ & $\begin{array}{c}0.022 \\
(0.015)\end{array}$ & $\begin{array}{c}0.028 \\
(0.018)\end{array}$ & $\begin{array}{r}0.029 \\
(0.016)\end{array}$ & $\begin{array}{r}0.020 \\
(0.014)\end{array}$ & $\begin{array}{r}0.025 \\
(0.019)\end{array}$ & $\begin{array}{r}0.047 \\
(0.021)\end{array}$ & $\begin{array}{r}0.022 \\
(0.013)\end{array}$ \\
\hline
\end{tabular}

$\mathrm{AB}=$ Alexander Bay; $\mathrm{BL}=$ Bloemfontein $; \mathrm{CT}=$ Cape Town; $\mathrm{DN}=$ Durban; $\mathrm{GR}=$ Grootfontein; $\mathrm{PE}=$ Port Elizabeth; PR = Pretoria; UP = Upington.

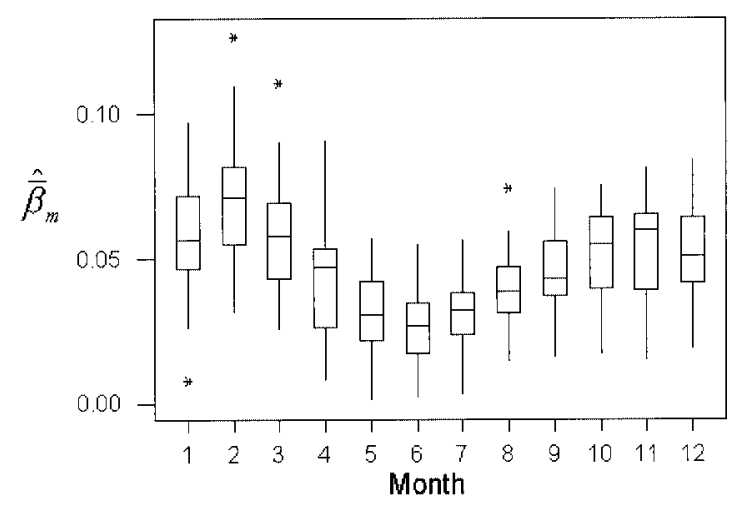

Figure 2. Boxplots of monthly estimates of Ångström's turbidity coefficient $\left(\hat{\bar{\beta}}_{m}\right)$ in Pretoria 1965-1997. Bloemfontein and Grootfontein also exhibited summer maxima and winter minima. Asterisks represent outliers in the data 


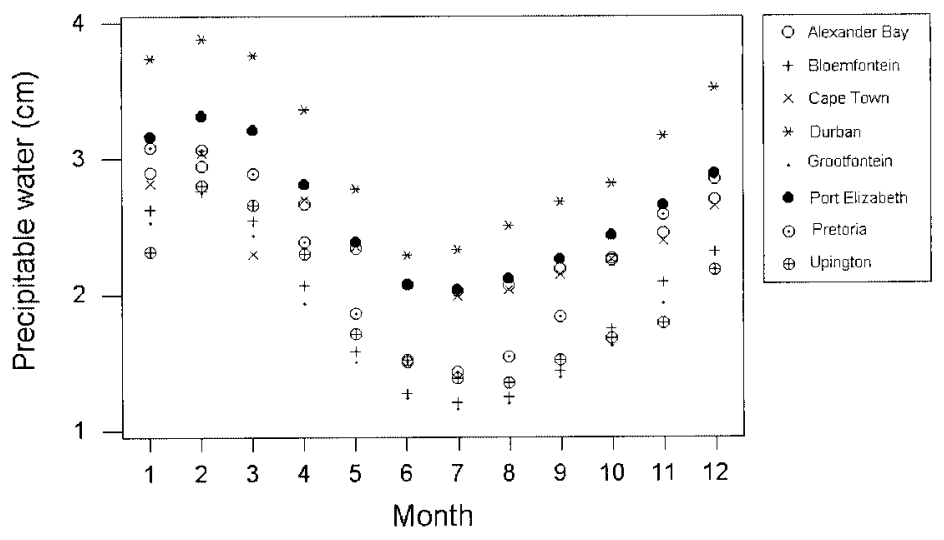

Figure 3. Long-term averages of monthly estimates of precipitable water $(w)$ at each of the eight climate stations. Stations at higher elevations (Upington, Grootfontein, Pretoria and Bloemfontein) are relatively dry, while the maritime environments of Durban, Port Elizabeth, Cape Town and Alexander Bay are characterized by higher atmospheric moisture

However, precipitable water is only one of many factors that can influence turbidity at any given location. Other climatic factors include convective activity, seasonal differences in air mass origin and the synoptic situation, as well as dispersion, transformation and removal processes. Indeed, precipitable water is highest in summer at all locations (Figure 3), yet Durban (Figure 4) and Alexander Bay, for example, exhibit peak turbidity in the winter.

Superimposed on the climatic influences is variability in the emissions of aerosols, particularly anthropogenic aerosols, and this further complicates interpretation of the aerosol signal. At stations with a summer maximum in turbidity (Bloemfontein, Grootfontein and Pretoria), it may be the ambient aerosol load in the atmospheric column that is being detected. At stations with other seasonal maxima, anthropogenic aerosols in the boundary layer - which are typically highest in winter-may dominate the aerosol signal. The climate station at Bloemfontein, for example, where turbidity is highest in summer, is located approximately $23 \mathrm{~km}$ east of the city where anthropogenic aerosols may play a lesser role in determining turbidity. Durban, in contrast, suffers from air pollution problems in the winter (D. Esterhuyse, personal communication, 2000) and this may contribute to the observed winter maxima in turbidity (Figure 4).

Turbidity in Cape Town is at a maximum in late winter and spring (Figure 5). With a population of over 2 million people, anthropogenic aerosols from the city may well influence turbidity at this station. Depending on the synoptic situation, maritime aerosols may also influence the turbidity signal in Cape

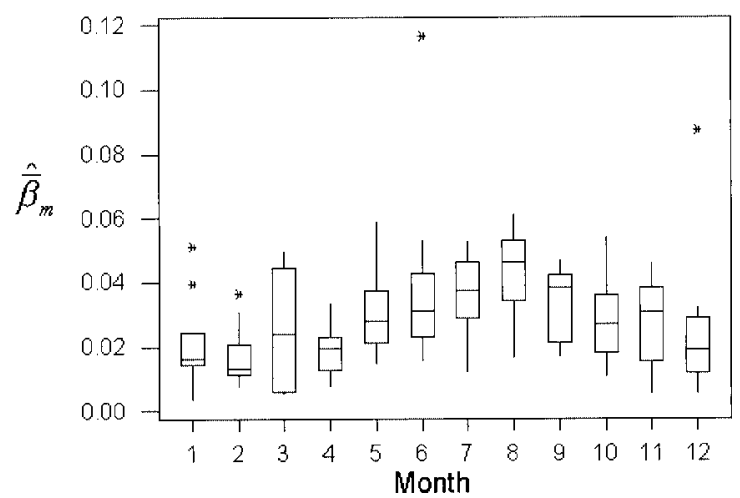

Figure 4. Boxplots of monthly estimates of Ångström's turbidity coefficient $\left(\hat{\bar{\beta}}_{m}\right)$ in Durban 1978-1991. Alexander Bay also demonstrated winter maxima. Asterisks represent outliers in the data 


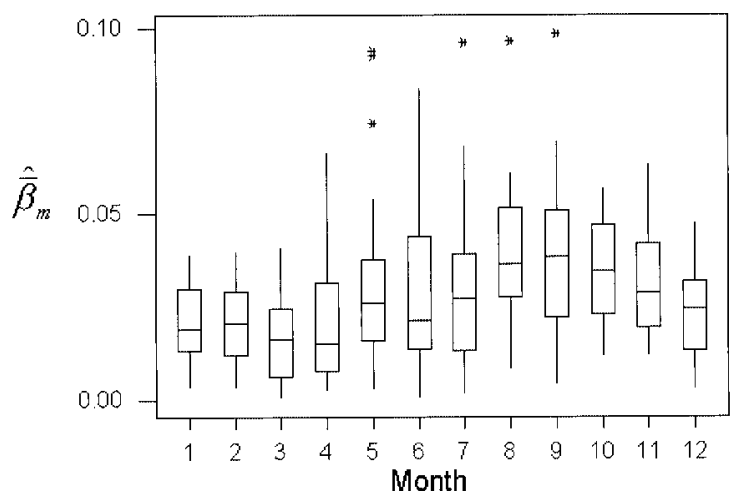

Figure 5. Boxplots of monthly estimates of Ångström's turbidity coefficient $\left(\hat{\bar{\beta}}_{m}\right)$ in Cape Town 1966-1995. Asterisks represent outliers in the data

Town, as well as in the other coastal stations in Alexander Bay, Port Elizabeth and Durban. Air masses originating from the Kalahari Desert may contribute to the aerosol load in Pretoria, Bloemfontein, Upington and Grootfontein. Clearly, there are many factors - both climatic and non-climatic - that determine turbidity patterns at any given location. It is difficult to attribute seasonal trends in turbidity to any one causal factor.

In an effort to quantify seasonal trends common among the eight stations, Pearson correlation coefficients $(r)$ were computed between the long-term monthly medians of the turbidity estimates at all stations $^{6}$ (Table III). This analysis corroborated the shared seasonal trends described above. Summer maxima in Bloemfontein and Pretoria, for instance, are reflected in the high $r$ value for these two stations (0.78). Of all the interstation comparisons, the highest positive correlations (for instance, those where $r \geq 0.7$ ) occur between coastal stations or between upland stations, with the exception of Port Elizabeth (coastal) and Bloemfontein (upland), and Upington (upland) and Port Elizabeth. Furthermore, a moderately high negative correlation $(r=-0.62)$ exists between Pretoria, in the mountains and Durban, on the east coast. These zonal associations may reflect the influence of synoptic climatology (e.g. dominant air masses or trajectories) on the aerosol climatology.

\subsection{Interannual variability and trends}

In order to examine long-term trends in turbidity over South Africa, moving averages of $\hat{\bar{\beta}}_{m}$ were computed at each station. Although interannual variability in turbidity is evident at all stations (Table II), at most stations turbidity is generally stable through the respective time series. However, a linear model

Table III. Pearson correlation coefficients $(r)$ between the long-term monthly medians of the $\left(\hat{\bar{\beta}}_{m}\right)$ estimates at the eight climate stations in South Africa

\begin{tabular}{lrrrrrrr}
\hline & \multicolumn{1}{c}{ AB } & \multicolumn{1}{l}{ BL } & \multicolumn{1}{l}{ CT } & DN & GR & PE & PR \\
\hline BL & -0.010 & & & & & & \\
CT & 0.858 & 0.225 & & & & & \\
DN & 0.713 & -0.323 & 0.740 & & & & \\
GR & 0.119 & 0.790 & 0.225 & -0.336 & & & \\
PE & 0.576 & 0.714 & 0.804 & 0.360 & 0.538 & & \\
PR & -0.437 & 0.782 & -0.227 & -0.617 & 0.574 & 0.285 & \\
UP & 0.503 & 0.699 & 0.554 & 0.061 & 0.584 & 0.755 & 0.537 \\
\hline
\end{tabular}

Key as for Table II. 
fit to the Cape Town and Grootfontein time series both show long-term trends in turbidity. In Cape Town, where the long-term averaged $\overline{\bar{\beta}}_{m}$ is $0.028, \overline{\bar{\beta}}_{m}$ has, on average, increased by approximately 0.022 between 1966 and 1995 (Figure 6). A simultaneous $0.47 \mathrm{~cm}$ average increase in monthly precipitable water $(w)$ (Figure 7) may be a contributing factor to the observed trend. Meanwhile, turbidity in Grootfontein appears to have decreased on average by 0.013 during the period 1969-1990 (Figure 8). Interestingly, a concomitant $0.80 \mathrm{~cm}$ average increase in monthly $w$ (Figure 9) suggests that the observed decrease in turbidity is probably the result of changes in other climatic factors and/or a reduction in aerosol emissions.

In Cape Town, a period of steadily increasing turbidity commenced in mid-1991 and continued until the end of 1994 (Figure 6). Similar temporal trends are evident in Pretoria (Figure 10) and Upington (not shown). Aerosols ejected from the June 1991 eruption of Mount Pinatubo may have contributed to these short-term trends. There is, however, no evidence of a post-Pinatubo increase in aerosols in Bloemfontein, while in Durban, Port Elizabeth, Grootfontein and Alexander Bay there are insufficient turbidity data after the eruption to enable the assessment of any possible effects on the aerosol climatology. A noticeable short-term increase in turbidity, commencing in 1963, is evident in Port Elizabeth (Figure 11), Alexander Bay and Bloemfontein (not shown). These trends may, in part, be attributable to the March 1963 eruption of Mount Agung in Indonesia. Such trends cannot be observed at other stations because the time series

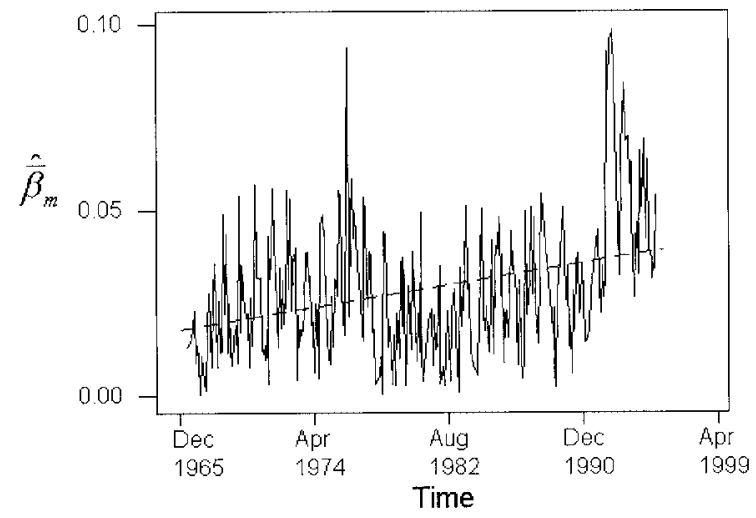

Figure 6. Linear trend model fit to monthly estimates of Ångström's turbidity coefficient $\left(\hat{\bar{\beta}}_{m}\right)$ for Cape Town 1966-1995. The model is $\overline{\bar{\beta}}_{i}=\left(1.77 \times 10^{-2}\right)+\left(6.00 \times 10^{-5} \times t_{i}\right)$ where $\overline{\bar{\beta}}_{i}$ is the estimated value of Ångström's turbidity coefficient for the $i$ th month and $t_{i}$ is the $i$ th month since January 1966

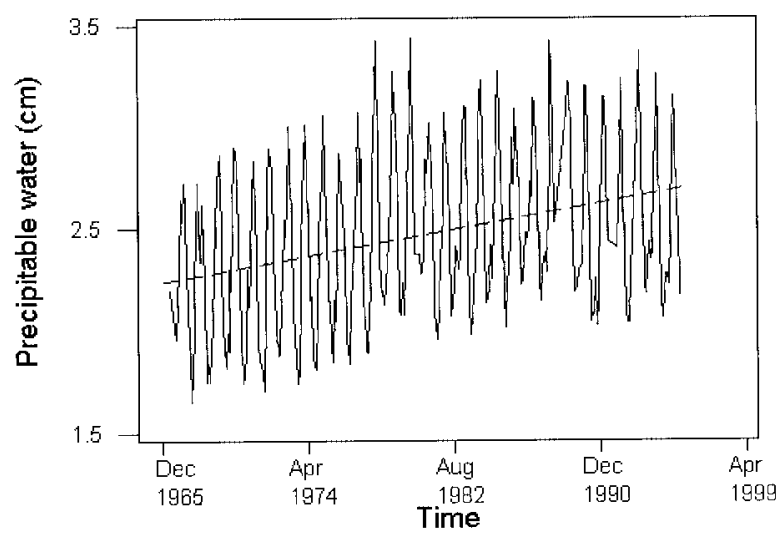

Figure 7. Linear trend model fit to monthly estimates of precipitable water $(w)$ for Cape Town 1966-1995. The model is $w_{i}=2.24+\left(1.3 \times 10^{-3} \times t_{i}\right)$, where $w_{i}$ is the estimated value of precipitable water for the $i$ th month and $t_{i}$ is the $i$ th month since January 1966 


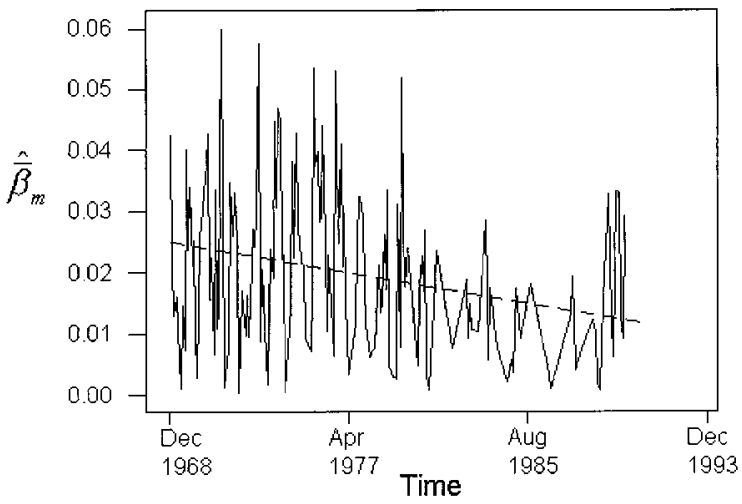

Figure 8. Linear trend model fit to monthly estimates of Ångström's turbidity coefficient $\left(\hat{\bar{\beta}}_{m}\right)$ for Grootfontein 1969-1990. The model is $\bar{\beta}_{i}=\left(2.50 \times 10^{-2}\right)-\left(5.06 \times 10^{-5} \times t_{i}\right)$, where $\bar{\beta}_{i}$ is the estimated value of Angström's turbidity coefficient for the $i$ th month and $t_{i}$ is the $i$ th month since January 1969

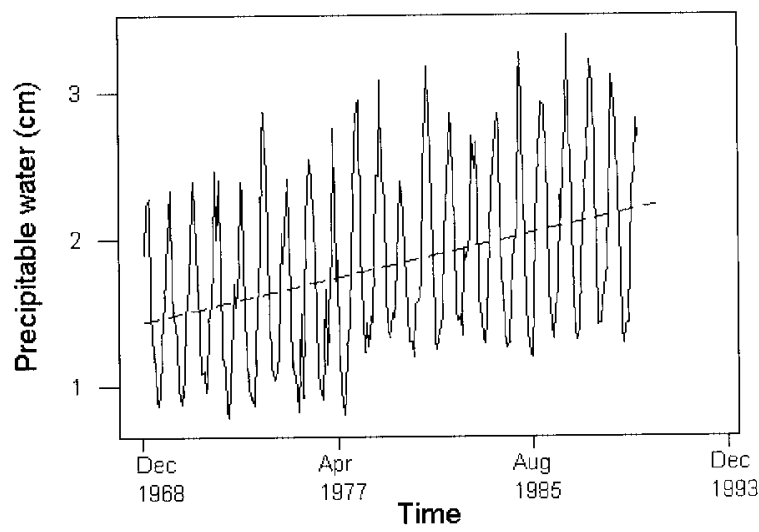

Figure 9. Linear trend model fit to monthly estimates of precipitable water $(w)$ for Grootfontein 1969-1990. The model is $w_{i}=1.44+\left(3.02 \times 10^{-3} \times t_{i}\right)$, where $w_{i}$ is the estimated value of precipitable water for the $i$ th month and $t_{i}$ is the $i$ th month since January 1969

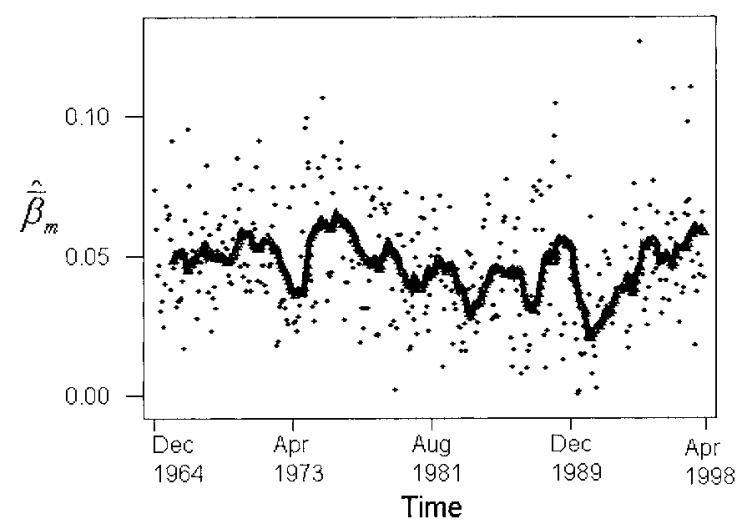

Figure 10. Monthly estimates and 12-monthly moving averages (solid line) of Ångström’s turbidity coefficient $\left(\hat{\bar{\beta}}_{m}\right)$ in Pretoria 1965-1997. The rise in turbidity commencing in 1991 was also evident in Cape Town and Upington 


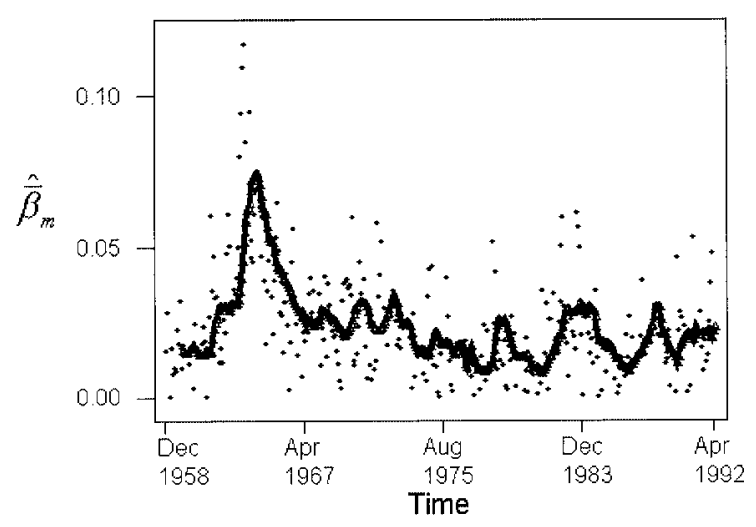

Figure 11. Monthly estimates and 12-monthly moving averages (solid line) of Ångström’s turbidity coefficient $\left(\hat{\bar{\beta}}_{m}\right)$ in Port Elizabeth 1959-1991. The peak in turbidity commencing in 1963 was also evident in Alexander Bay and Bloemfontein

begin later than 1963 (Table I). The 1982 eruption of El Chichón does not appear to be detectable in any of the turbidity signatures.

It appears that the majority of stations show no evidence of any long-term changes in turbidity. Furthermore, because turbidity patterns are not consistent across all stations, the long-term trends that do exist (in Cape Town and Grootfontein) are probably the result of local or regional changes in climate or in aerosol emissions (natural or anthropogenic). The long-term trend identified in Cape Town should also be interpreted with caution; without the 1991-1994 increase, which may be due to the Pinatubo eruption, turbidity would appear to be relatively stable. As with the seasonal trends identified above, it is difficult to determine the relative importance of climatic changes versus emission patterns on long-term trends and variability in turbidity.

\section{CONCLUSIONS}

This research provides a preliminary climatology of aerosols previously unavailable for South Africa. Compared with the Northern Hemisphere, turbidity in South Africa was found to be very low. The highest turbidities are in the larger cities of Cape Town, Durban and Pretoria, while the smaller townships are characterized by relatively low turbidity. Seasonal trends are evident at many stations, although there is no consistent trend. Over recent decades, turbidity has generally been stable at most stations in South Africa. Exceptions include Cape Town, where there has been an increase in turbidity over the last 30 years, and Grootfontein, where turbidity appears to have decreased over the 25 -year record. The eruptions of Mount Pinatubo and Mount Agung appear to be detectable in the turbidity signatures at some stations.

Although the present application is limited to South Africa, atmospheric turbidity can be estimated, regardless of cloud cover, wherever the requisite climate data are available. The methodology, therefore, offers the potential for more extensive aerosol climatologies than are currently available.

\section{ACKNOWLEDGEMENTS}

The assistance provided by Brian Hanson, Christian Gueymard, John Schuenemeyer and Joseph Michalsky was appreciated. Johan Koch and Danie Esterhuyse, of the SAWB, kindly provided climate data for South Africa. Financial support from the Geography and Regional Science Program of the National Science Foundation (SBR 97-09667) is gratefully acknowledged. 
APPENDIX A. COEFFICIENTS $c_{i}$ AND $\varphi_{i}$

\begin{tabular}{lrr}
\hline$i$ & \multicolumn{1}{l}{$c_{i}$} & \multicolumn{1}{l}{$\varphi_{i}$} \\
\hline 0 & 0.874744 & 0.023009 \\
1 & -3.764677 & 3.718631 \\
2 & -0.053730 & -6.209335 \\
3 & -0.006222 & 4.840892 \\
4 & -0.079219 & -0.670249 \\
5 & -0.001977 & -1.406449 \\
6 & & 0.936992 \\
7 & & -0.159847
\end{tabular}

\section{APPENDIX B. SOLUTIONS TO THE $J_{i}=\int_{0}^{\omega_{0}} \sin ^{i} h \mathrm{~d} \omega$ INTEGRALS}

$$
\begin{aligned}
J_{0}= & \omega_{0} \\
J_{1}= & q\left(\sin \omega_{0}-\omega_{0} \cos \omega_{0}\right) \\
J_{2}= & q^{2}\left[\omega_{0}\left(\frac{1}{2}+\cos ^{2} \omega_{0}\right)-\frac{3}{4} \sin 2 \omega_{0}\right] \\
J_{3}= & q^{3}\left[\sin \omega_{0}\left(\frac{2}{3}+\frac{11}{6} \cos ^{2} \omega_{0}\right)-\omega_{0} \cos \omega_{0}\left(\frac{3}{2}+\cos ^{2} \omega_{0}\right)\right] \\
J_{4}= & q^{4}\left[\omega_{0}\left(\frac{3}{8}+3 \cos ^{2} \omega_{0}+\cos ^{4} \omega_{0}\right)-\sin 2 \omega_{0}\left(\frac{55}{48}+\frac{25}{24} \cos ^{2} \omega_{0}\right)\right] \\
J_{5}= & q^{5}\left[\sin \omega_{0}\left(\frac{8}{15}+\frac{607}{120} \cos ^{2} \omega_{0}+\frac{137}{160} \cos ^{4} \omega_{0}\right)-\omega_{0} \cos \omega_{0}\left(\frac{15}{8}+5 \cos ^{2} \omega_{0}+\cos ^{4} \omega_{0}\right)\right] \\
J_{6}= & q^{6}\left[\omega_{0}\left(\frac{5}{16}+\frac{45}{8} \cos ^{2} \omega_{0}+\frac{15}{2} \cos ^{4} \omega_{0}+\cos ^{6} \omega_{0}\right)-\sin 2 \omega_{0}\left(\frac{231}{160}+\frac{91}{20} \cos ^{2} \omega_{0}+\frac{49}{20} \cos ^{4} \omega_{0}\right)\right] \\
J_{7}= & -\frac{1}{8960}\left[q ^ { 7 } \left(171500 \omega_{0} \cos \omega_{0}+61740 \omega_{0} \cos 3 \omega_{0}+6860 \omega_{0} \cos 5 \omega_{0}+140 \omega_{0} \cos 7 \omega_{0}\right.\right. \\
& \left.\left.-42875 \sin \omega_{0}-48363 \sin 3 \omega_{0}-9947 \sin 5 \omega_{0}-363 \sin 7 \omega_{0}\right)\right] \\
J_{8}= & \frac{1}{35840}\left[q ^ { 8 } \left(686000 \omega_{0}+878080 \omega_{0} \cos 2 \omega_{0}+219520 \omega_{0} \cos 4 \omega_{0}+17920 \omega_{0} \cos 6 \omega_{0}\right.\right. \\
& \left.\left.+280 \omega_{0} \cos 8 \omega_{0}-395136 \sin 2 \omega_{0}-208554 \sin 4 \omega_{0}-28544 \sin 6 \omega_{0}-761 \sin 8 \omega_{0}\right)\right],
\end{aligned}
$$

where $q=\cos \phi \cos \delta, \phi$ is the latitude and $\delta$ is the solar declination.

\section{NOTES}

1. Ångström's turbidity coefficient $(\beta)$ is a dimensionless measure of turbidity which is defined as the aerosol optical depth at a wavelength of $1.0 \mu \mathrm{m}$. Values of $\beta$ typically range from 0.02 , for a low aerosol load, to 0.5 , for a high aerosol load.

2. Bright sunshine duration $(s)$ is defined as the number of hours per day that the sunshine intensity exceeds some predetermined threshold of brightness. 
3. Willmott's index of agreement $(d)$ is a dimensionless statistic that varies between 0.0 and 1.0 , where a value of 1.0 indicates perfect agreement between two variables and 0.0 describes complete disagreement.

4. In estimating monthly $u_{o}$, and calculating $E_{0 n}, \omega_{0}$ and $S$, the climatologically average day of the month was based on the average solar declination and earth-sun distance for the month.

5. Population data were 1991 estimates (United Nations, 1999). See Table I.

6. Median values were used, rather than means, to avoid the possible influence of outliers in the data.

\section{REFERENCES}

Adeyefa ZD, Holmgren B, Adedokun JA. 1997. Spectral solar radiation measurements and turbidity: comparative studies within a tropical and sub-arctic environment. Solar Energy 60(1): 17-24.

Al-Jamal K, Ayyash S, Rasas M, Al-Aruri S, Shaban N. 1987. Atmospheric turbidity in Kuwait. Atmospheric Environment 21(8): $1855-1859$.

Benson RB, Paris MV, Sherry JE, Justus CG. 1984. Estimation of daily and monthly direct, diffuse and global solar radiation from sunshine duration measurements. Solar Energy 32: 523-535.

Blumthaler M, Ambach W, Blasbichler A. 1997. Measurements of the spectral aerosol optical depth using a sun photometer. Theoretical and Applied Climatology 57: 95-101.

Cerf A. 1980. Atmospheric turbidity over West-Africa. Contributions to Atmospheric Physics 53(3): 414-429.

Charlson RJ, Schwartz SE, Hales JM, Cess RD, Coakley JA Jr, Hansen JE, Hofmann DJ. 1992. Climate forcing of anthropogenic aerosols. Science 255: 423-430.

Chiapello I, Bergametti G, Chatenet B, Dulac F, Jankowiak I, Liousse C, Soares ES. 1999. Contribution of the different aerosol species to the aerosol mass load and optical depth over the northeastern tropical Atlantic. Journal of Geophysical Research 104(D4): 4025-4035.

Christopher SA, Kliche DV, Chou J, Welch RM. 1996. First estimates of the radiative forcing of aerosols generated from biomass burning using satellite data. Journal of Geophysical Research 101: 21 265-21 273.

Dutton EG, Reddy P, Ryan S, DeLuisi JJ. 1994. Features and effects of aerosol optical depth observed at Mauna Loa, Hawaii: 1982-1992. Journal of Geophysical Research 99(D4): 8295-8306.

Freund J. 1983. Aerosol optical depth in the Canadian Arctic. Atmosphere-Ocean 21(2): 158-167.

Garrison JD, Sahami K. 1995. Analysis of clear sky solar radiation for seven Canadian sites. Solar Energy 55(6): 505-512.

Gueymard C. 1993. Mathematically integrable parameterization of clear-sky beam and global irradiances and its use in daily irradiation applications. Solar Energy 50(5): 385-397.

Gueymard C. 1994. Analysis of monthly average atmospheric precipitable water and turbidity in Canada and northern United States. Solar Energy 53(1): 57-71.

Gueymard C. 1995. SMARTS2, Simple Model of the Atmospheric Radiative Transfer of Sunshine: Algorithms and Performance Assessment, Rep. FSEC-PF-270-95, Florida Solar Energy Center.

Gueymard C, Garrison JD. 1998. Critical evaluation of precipitable water and atmospheric turbidity in Canada using measured hourly solar irradiance. Solar Energy 62(4): 291-307.

Herber A, Wendisch M, Leiterer U, Notholt J. 1991. Measurements of the optical depth and retrieval of aerosol parameters in the polar regions. Journal of Aerosol Science 22(Suppl 1): S415-S418.

Herber A, Thomason LW, Dethloff K, Viterbo P, Radionov VF, Leiterer U. 1996. Volcanic perturbation of the atmosphere in both polar regions: 1991-1994. Journal of Geophysical Research 101(D2): 3921-3928.

Holben BN, Setzer A, Eck TF, Pereira A, Slutsker I. 1996. Effect of dry-season biomass burning on Amazon basin aerosol concentrations and optical properties, 1992-1994. Journal of Geophysical Research 101(D14): 19465-19481.

Holben BN, Eck TF, Slutsker I, Tanré D, Buis JP, Setzer A, Vermote E, Reagan JA, Kaufman YJ, Nakajima T, Lavenu F, Jankowiak I, Smirnov A. 1998. AERONET - a federated instrument network and data archive for aerosol characterization. Remote Sensing Environment 66: 1-16.

Husar RB, Prospero JM, Stowe LL. 1997. Characterization of tropospheric aerosols over the oceans with the NOAA advanced very high resolution radiometer optical thickness operational product. Journal of Geophysical Research 102(D14): 16 889-16909.

Jacovides CP, Timbios FS, Giannourakos GP. 1996a. Recent measurements of broad-band turbidity parameters in the island of Cyprus. Atmospheric Environment 30(20): 3391-3396.

Jacovides CP, Kassomenos P, Kaltsunides NA. 1996b. Estimates of effective aerosol optical depths from spectral solar radiation measurements. Theoretical and Applied Climatology 53: 211-220.

Kambezidis HD, Katevatis EM, Petrakis M, Lykoudis S, Asimakopoulos DN. 1998. Estimation of the Linke and Unsworth-Monteith turbidity factors in the visible spectrum: application for Athens, Greece. Solar Energy 62(1): 39-50.

Kaufman YJ, Fraser RS, Mahoney RL. 1991. Fossil fuel and biomass burning effect on climate-heating or cooling? Journal of Climate 4: $578-588$.

Kiehl JT. 1999. Solving the aerosol puzzle. Science 283: 1274-1275.

Louche A, Maurel M, Simonnot G, Peri G, Iqbal M. 1987. Determination of Ångström's turbidity coefficient from direct total solar irradiance measurements. Solar Energy 38(2): 89-96.

Louche A, Notton G, Poggi P, Simonnot G. 1991. Correlations for direct normal and global horizontal irradiation on a French Mediterranean site. Solar Energy 46(4): 261-266.

Maduekwe AAL, Chendo MAC. 1997. Atmospheric turbidity and the diffuse irradiance in Lagos, Nigeria. Solar Energy 61(4): 241-249.

Penner JE, Dickinson RE, O’Neill CA. 1992. Effects of aerosol from biomass burning on the global radiation budget. Science 256: 1432-1434. 
Penner JE, Charlson RJ, Hales JM, Laulainen NS, Leifer R, Novakov T, Ogren J, Radke LF, Schwartz SE, Travis L. 1994 Quantifying and minimizing uncertainty of climate forcing by anthropogenic aerosols. Bulletin of the American Meteorological Society 75(3): $375-400$.

Peterson JT, Flowers EC. 1977. Interactions between air pollution and solar radiation. Solar Energy 19: 23-32.

Pinker RT, Ferrare RA, Karnieli A, Aro TO, Kaufman YJ, Zangvil A. 1997. Aerosol optical depths in a semiarid region. Journal of Geophysical Research 102(D10): $11123-11137$.

Power HC. 1999. Modeling seasonal and interannual variability in atmospheric turbidity with application to South Africa. PhD Dissertation. University of Delaware, Newark.

Power HC. 2001a. Estimating atmospheric turbidity from climate data. Atmospheric Environment 35(1): 125-134.

Power HC. 2001b. Estimating clear-sky beam irradiation from sunshine duration. Solar Energy. Accepted.

Prodi F, Levizzani V, Sentimenti M, Colombo T, Cundari V, Zanzu T, Juliano V. 1984. Measurements of atmospheric turbidity from a network of sun-photometers in Italy during ALPEX. Journal of Aerosol Science 15(5): 595-613.

Russell PB, Hobbs PV, Stowe LL. 1999. Aerosol properties and radiative effects in the United States east coast haze plume: an overview of the Tropospheric Aerosol Radiative Forcing Observational Experiment (TARFOX). Journal of Geophysical Research 104(D2): 2213-2222.

Sadler GW. 1978. Turbidity of the atmosphere at solar noon for Edmonton, Alberta, Canada. Solar Energy 21: $339-342$.

Shaw GE. 1982. Atmospheric turbidity in the polar regions. Journal of Applied Meteorology 21: 1080-1088.

Tanré D, Herman M, Kaufman YJ. 1996. Information on aerosol size distribution contained in solar reflected spectral radiances. Journal of Geophysical Research 101(D14): 19043-19060.

Trenberth KE. 1996. Coupled climate system modelling. In Climate Change: Developing Southern Hemisphere Perspectives, Giambelluca TW, Henderson-Sellers A (eds). John Wiley \& Sons: Chichester; 3-26.

Uboegbulam TC, Davies JA. 1983. Turbidity in Eastern Canada. Journal of Climate and Applied Meteorology 22: $1384-1392$.

United Nations. 1999. Demographic Yearbook, 49th issue, Department of Economic and Social Affairs, Publication No. E/F.99.XIII.1.

Van Heuklon TK. 1979. Estimating atmospheric ozone for solar radiation models. Solar Energy 22: 63-68.

Veefkind JP, de Leeuw G. 1998. A new algorithm to determine the spectral aerosol optical depth from satellite radiometer measurements. Journal of Aerosol Science 29(10): 1237-1248.

Veefkind JP, de Leeuw G, Durkee PA, Russell PB, Hobbs PV, Livingston JM. 1999. Aerosol optical depth retrieval using ATSR-2 and AVHRR data during TARFOX. Journal of Geophysical Research 104(D2): 2253-2260.

Villevalde YV, Smirnov AV, O’Neill NT, Smyshlyaev SP, Yakovlev VV. 1994. Measurement of aerosol optical depth in the Pacific Ocean and the North Atlantic. Journal of Geophysical Research 99(D10): 20 983-20 988.

von Hoyningen-Huene W, Wenzel K, Schienbein S. 1999. Radiative properties of desert dust and its effect on radiative balance. Journal of Aerosol Science 30(4): 489-502.

Wigley TML. 1989. Possible climate change due to $\mathrm{SO}_{2}$ derived cloud condensation nuclei. Nature 339: 355-357.

Wigley TML, Raper SCB. 1992. Implications for climate and sea level of revised IPCC emissions scenarios. Nature 357: 293-300.

Willmott CJ, Ackleson SG, Davis RE, Feddema JJ, Klink KM, Legates DR, O'Donnell J, Rowe CM. 1985. Statistics for the evaluation and comparison of models. Journal of Geophysical Research 90(C5): 8995-9005.

Wolf ME, Hidy GM. 1997. Aerosols and climate: anthropogenic emissions and trends for 50 years. Journal of Geophysical Research 102(D10): $11113-11121$.

Yatko B, Garrison JD. 1996. An evaluation of the effect of volcanic eruption on the solar radiation at Australian and Canadian stations. In Proceedings of Solar '96, The 1996 American Solar Energy Society Annual Conference, Asheville, North Carolina, 13-18 April 1996, Campbell-Howe R, Wilkins-Crowder B (eds). American Solar Energy Society: Boulder, CO. 